\title{
How Old is "Cinder Cone"?-Solving a Mystery in Lassen Volcanic National Park, California
}

\section{inder Cone in Lassen Vol- canic National Park is a 700-foot-high volcanic cone. Its age has been controversial since the 1870's, when many people thought it was only a few decades old. Later, the cone and associated lava flows were thought to have formed about A.D. 1700 or during a 300 -year- long series of eruptions ending in 1851. However, recent studies by U.S. Geological Survey (USGS) scientists, working in cooperation with the National Park Service to better under- stand volcano hazards in the Lassen area, have firmly estab- lished that Cinder Cone was formed in eruptions about 1650.}

After traveling through northern California in the spring of 1851, two gold prospectors reported seeing an erupting volcano that "threw up fire to a terrible height." They further claimed that they walked 10 miles over rocks so hot that their boots were entirely destroyed. Their story is only one of several reports from that time that were later assumed to describe an eruption of "Cinder Cone," a volcanic feature located in what is now the northeast corner of Lassen Volcanic National Park.

Cinder Cone is a 700-foot-high cone of loose scoria. Scoria forms when blobs of gascharged lava are thrown into the air during an eruption and cool in flight, falling as dark volcanic rock containing cavities created by trapped gas bubbles. The summit of Cinder Cone has a crater with a double rim, probably created by fluctuating eruptive activity late in its formation. The cone also has several associated blocky lava flows, and a related, widespread ash deposit identifiable for 8 to 10 miles from the cone.

There are actually two scoria cones at Cinder Cone-the remnants of a nearly completely

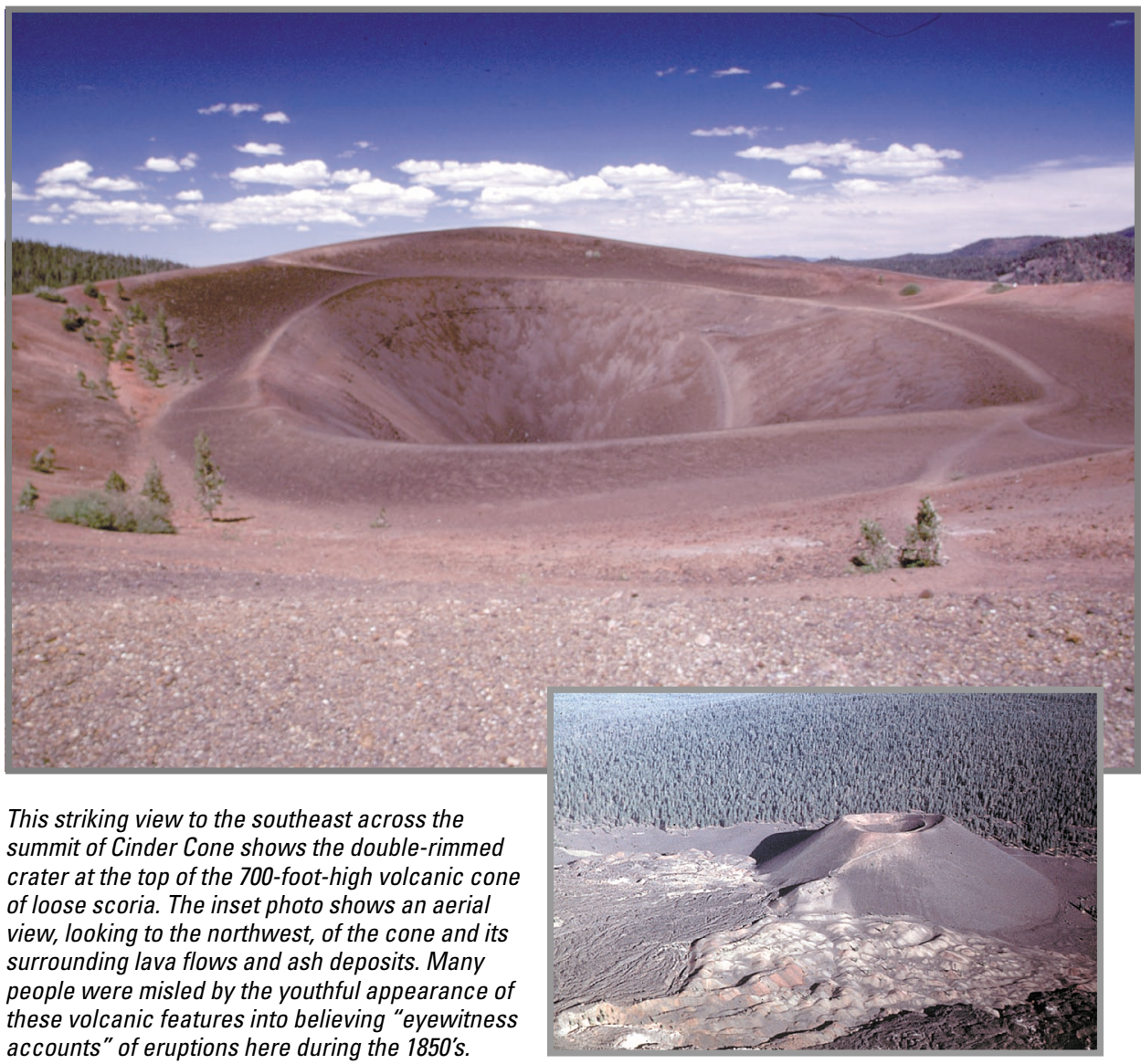

buried earlier cone can be seen on the larger cone's south side. Much of the earlier cone was probably destroyed by lava flows erupting from its base. Blocks of red, cemented scoria within the Painted Dunes lava flows (see geologic map) are pieces of this earlier cone, which were carried away by the flowing lava.

\section{Beginnings of a Controversy}

The eruptions and volcanic history of Cinder Cone have been an ongoing controversy for more than a century, in part because of the starkly beautiful contrast between the very new looking, unvegetated cone and lava flows and the surrounding mature forest. In the early 1870's, H.W. Harkness, a medical doctor and observant amateur scientist from San Francisco, visited and described the Cinder Cone area (Harkness, 1875). He was impressed by the apparent youthfulness of the volcanic features, and described a number of lines of evidence that he interpreted to mean that Cinder Cone was only about 25 years old.

After presenting his findings at a meeting of the California Academy of Sciences, Harkness was contacted by Henry Chapman, an Academy member, who told him of hearing the gold prospectors tell their story. He was also contacted by several others who claimed to have witnessed a volcanic eruption in the Wozencraft. Harkness thought that all these tales of volcanic activity might be related to an eruption of Cinder Cone.

The circumstances surrounding these reports are somewhat obscure and inconsistent. Several reports of "volcanic eruptions" in the Lassen area had appeared in northern California newspapers in the 1850's, but Harkness was probably unaware of them. In the earliest of these, published in the August 21, 1850, edition of the Daily Pacific News, a San FranLassen area around 1851, including a Dr. O.M. 


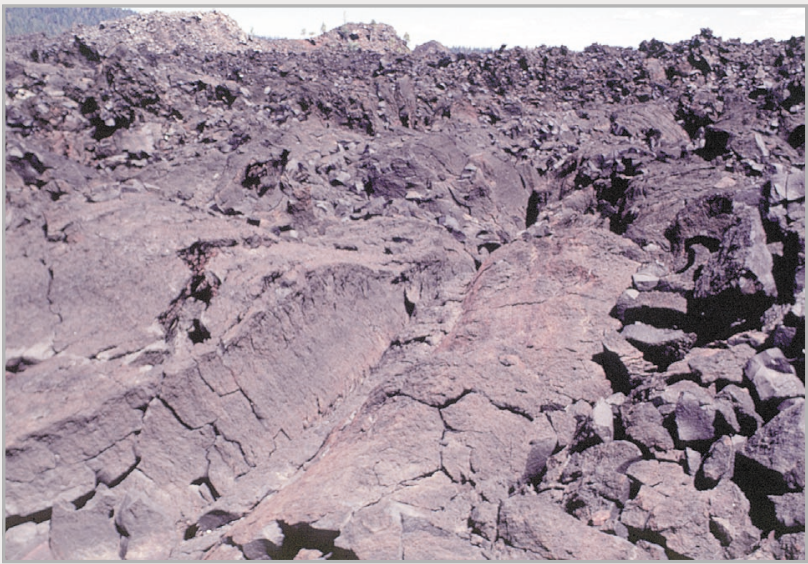

This extremely young looking lava flow (Fantastic Lava Beds flow 2; see geologic map) was the last flow erupted at Cinder Cone. Its unweathered, rough surface misled early visitors into believing that it had been erupted no more than a few decades before.

cisco newspaper, an unnamed observer reported seeing an erupting volcano with "burning lava still running down the sides." In 1859, the San Francisco Times printed an article in which Dr. Wozencraft and a companion were purported to have seen, from a position somewhere west of the Lassen area, flames in the sky that they attributed to a volcanic eruption. This article was widely reprinted and popularized in other papers, but no specific date or location was given for their sighting. The Shasta Republican noted on several occasions in April 1859 that "the Dr.'s imagination is far more active than any volcano in our County or State." It was in Harkness' 1875 report that the date of Wozencraft's observation is first mentioned to be the winter of 1850-51.

\section{Early Geologic Studies}

The first geologist to study Cinder Cone was Joseph Diller (Diller, 1891, 1893), who was among the first U.S. Geological Survey (USGS) scientists to study volcanoes. Diller made careful observations of Cinder Cone and interviewed many Native Americans and European trappers and settlers who were in the Lassen region in 1850 . None of them could recall witnessing any volcanic activity in the area. Diller knew that an "emigrant road" (the Nobles Trail), used by settlers coming to California in the early 1850's, passes close to the base of Cinder Cone. He spoke with several people who had "crossed the trail" in 1853. They noted that a large, solitary willow bush (Salix scouleriana) near the summit of Cinder Cone was "as large then as now." Today, more than a century after Diller's interviews, this bush is still alive and little changed.

Because the "Scouler willow" at the summit of Cinder Cone was already mature in 1853 ,

The first geologist to study Cinder Cone was Joseph $S$. Diller. He made many careful observations and correctly concluded in his 1891 report that "Whatever may be the historical testimony as to the time of the eruption, the geologic evidence clearly demonstrates that it must have occurred long before the beginning of the present century" (before 1800).
Diller concluded it was extremely unlikely that an eruption could have occurred there in the winter of 1850 . He also noted that trees rooted in volcanic ash erupted from the cone were about 200 hundred years old and that the oldest trees on related lava flows were about 150 years old. Diller believed he recognized two eruptive sequences, which each produced lava flows. However, he thought that only the older eruption was explosive, creating Cinder Cone and the ash deposits. In regard to the explosive eruption, he concluded that "Whatever may be the historical testimony as to the time of the eruption, the geologic evidence clearly demonstrates that it must have occurred long before the beginning of the present century" (before 1800). Diller therefore speculated that the explosive eruption had occurred between about A.D. 1675 and 1700 and that the younger, quiet eruption was "certainly" sometime before 1840 .

In the mid-1930's, USGS volcanologist R.H. Finch attempted to improve on Diller's work. On the basis of other studies done at

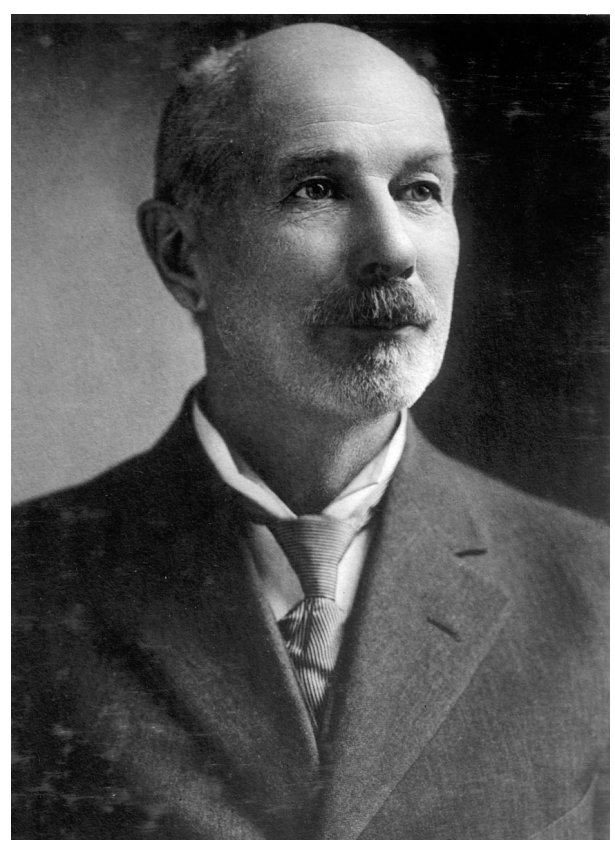

Cinder Cone, Finch thought (1) that there had been at least five separate lava-flow events, as suggested by crude, experimental magnetic measurements (Jones, 1928); (2) that the youngest lava flow was extruded in 1851, accepting Harkness' (1875) historical "evidence" and ignoring Diller's interviews and conclusions; and (3) that there had been at least two distinct explosive eruptions of the cone (Finch and Anderson, 1930). Using these assumptions and tree-ring measurements, Finch proposed a complex and detailed eruptive chronology for Cinder Cone that spanned nearly 300 years (Finch, 1937). From measurements of the rings of one particular tree, which showed two periods of slow growth, he thought that the two explosive eruptions occurred in A.D. 1567 and 1666. He also concluded that the five lava flows were extruded in 1567, 1666, 1720, 1785, and 1851.

\section{New Geologic Studies}

After Finch published his work in 1937, few additional studies were done on volcano hazards in the Lassen area. However, that changed on May 18, 1980, when Mount St. Helens, Washington, exploded in one of the most devastating volcanic eruptions of the 20th century. After the eruption, the USGS began reevaluating the risks posed by other potentially active volcanoes in the Cascade Range, including those in Lassen Volcanic National Park. Since that time, USGS scientists have been working in cooperation with the National Park Service to better understand volcano hazards in the Lassen area. As part of this work, the history of Cinder Cone has been reexamined. Most of the features of Cinder Cone have changed little since Harkness first described them in the 1870's, but all of the assumptions on which Finch based his conclusions have now been shown to be incorrect.

Through new field and laboratory work and by reinterpreting data from previous studies, USGS scientists have shown that the entire eruptive sequence at Cinder Cone represents a single continuous event. During this event, the composition of the molten rock (magma) feeding the eruption changed from basaltic andesite to andesite and then back to basaltic andesite, but with a higher titanium content. Chemically, basaltic andesites are volcanic rocks containing 53 to $57 \%$ silica $\left(\mathrm{SiO}_{2}\right)$, and andesites are those containing 57 to $63 \%$ silica. Though chemically distinct, the lava flows and scorias at Cinder Cone are similar in appearance. They are dark, fine-grained rocks, containing a few visible crystals of the minerals olivine, plagioclase, and quartz.

The earlier erupted group of volcanic deposits at Cinder Cone, which are relatively titanium-poor, consist of the older scoria cone, the Old Bench flow, the two Painted Dunes flows, and the lower part of the widespread 

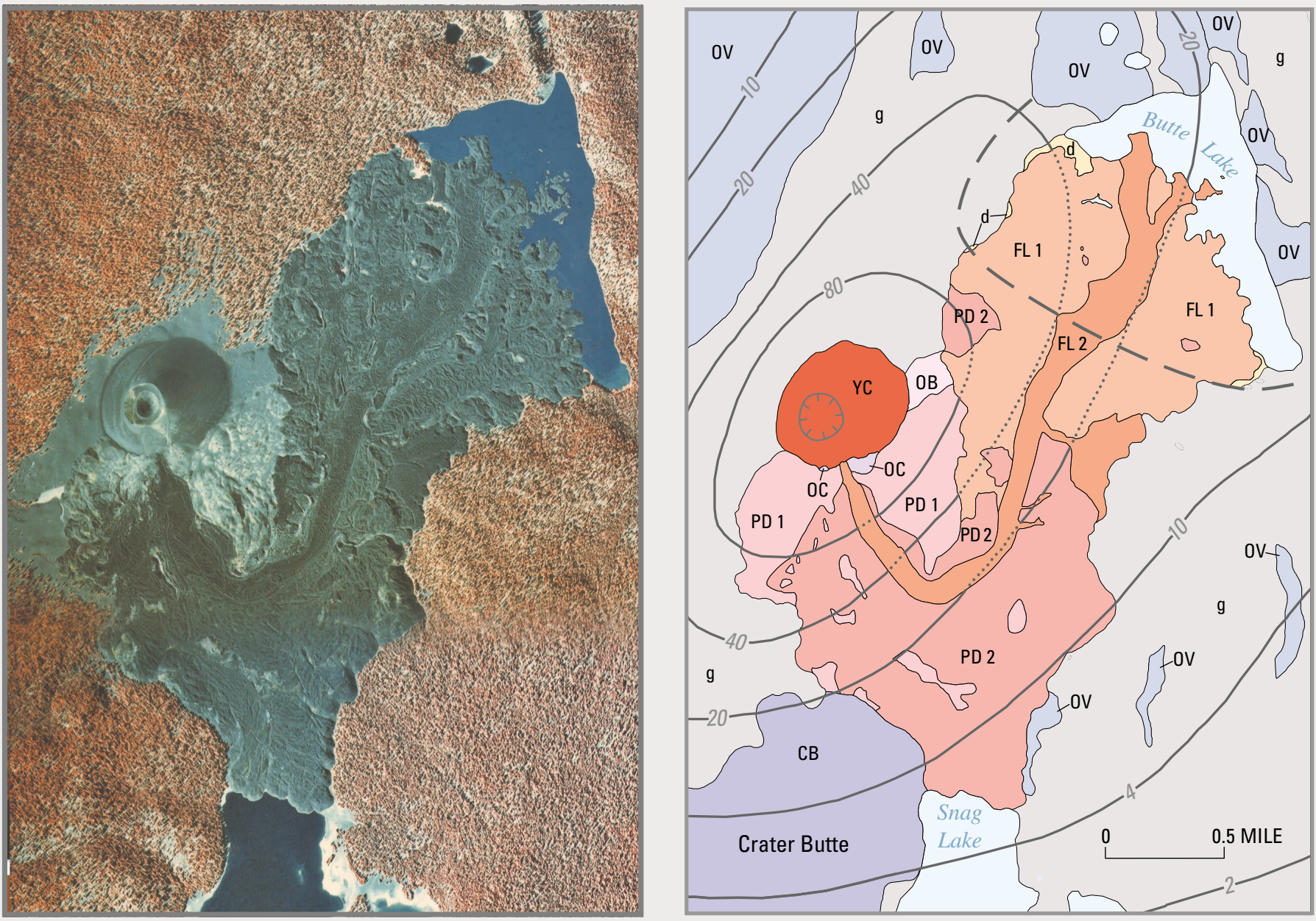

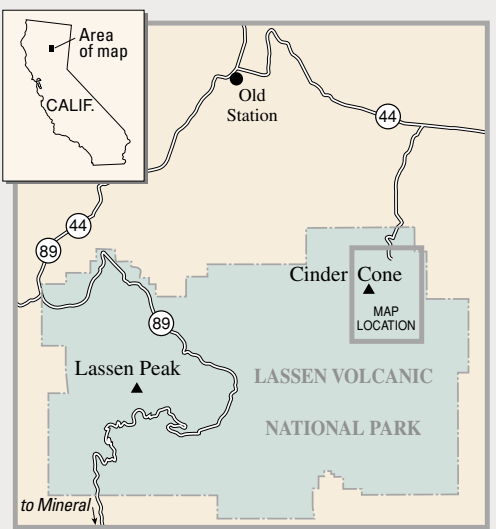

ash layer. The later erupted, relatively titanium-rich group consists of the large, younger scoria cone, the upper part of the ash layer, and the two Fantastic Lava Beds flows. Flow 2 of the Fantastic Lava Beds (see geologic map) is the flow that everyone but Diller thought had been erupted in 1851 .

The ash on the Old Bench and Painted Dunes lava flows is brightly oxidized because it fell on the lava flows when they were still hot. This oxidized ash belongs to the same compositional group as the Fantastic Lava

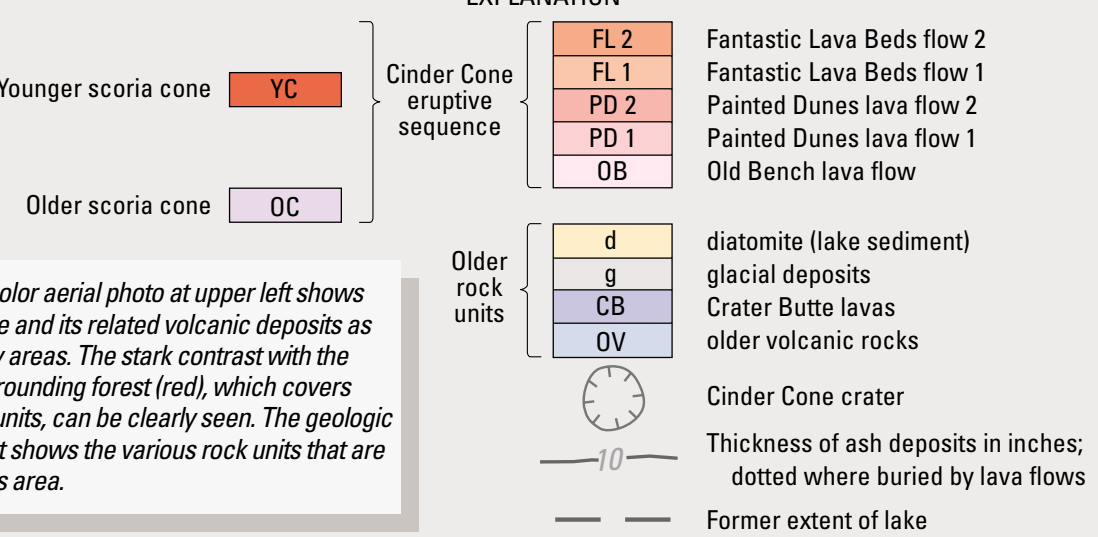

Beds flows, the last flows erupted at Cinder Cone. All the volcanic materials at Cinder Cone therefore represent a single eruptive sequence that probably spanned no more than a few months.

Another line of evidence for this conclusion is the "paleomagnetic" record preserved in Cinder Cone's lava flows. As lava cools, the local orientation of the Earth's magnetic field at that time is recorded in the rock as a "remanent" magnetization. If the pattern of past variations in the orientation of the Earth's magnetic field in a region is known, scientists can compare a remanent magnetization to that pattern and may be able to identify one or more time periods as short as a few decades in which the flow could have cooled. Because the orientation of the Earth's magnetic field in northern California during the 1850's is well known and is different from the remanent magnetizations at Cinder Cone, the lava flows there could not have been erupted in 1850 or 1851. Also, there are no discernible differences in the magnetic orientation recorded by 


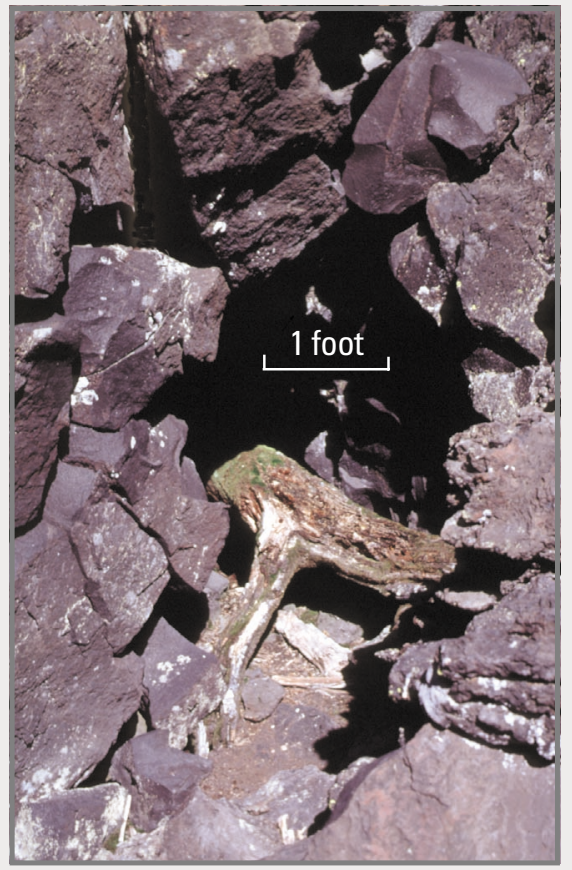

any of the Cinder Cone lava flows, and so the flows had to be extruded during an interval of less than 50 years.

Although paleomagnetic evidence can be used to rule out the 1850's as the age of Cinder Cone, it does not provide an actual age for its eruption. By measuring levels of carbon-14 in samples of wood from trees killed by the

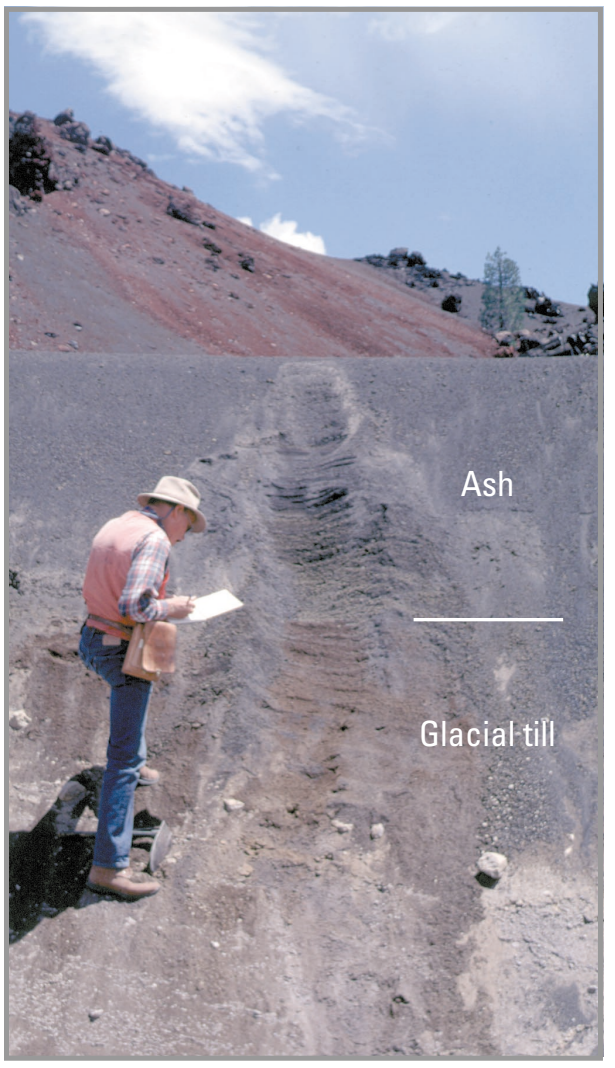

This trunk of a "quaking aspen," a tree that grows in wet ground near lakes or streams, was toppled and partly buried by flow 1 of the Fantastic Lava Beds. A wood sample from this tree provided a radiocarbon age that helped U.S. Geological Survey scientists confirm that the eruption of Cinder Cone occurred between A.D. 1630 and 1670. Additional radiocarbon ages that are consistent with this age were obtained from drowned trees in Snag Lake (see geologic map). This lake formed when the Painted Dunes lava flows blocked Grassy Creek, a stream draining the central plateau of Lassen Volcanic National Park.

Water from Snag Lake seeps beneath the Cinder Cone lava flows to supply Butte Lake, 2 miles to the north. Butte Lake is a remnant of a larger lake that was partly filled by lava flows during the eruption of Cinder Cone. A distinctive type of sediment, called diatomite, found along the margins of the Fantastic Lava Beds flows helps to indicate the former extent of that larger lake, as does the quaking aspen, which grew near the lake's edge. The diatomite was

eruption of Cinder Cone, USGS scientists obtained a "radiocarbon" date for the eruption of between A.D. 1630 and 1670. Such a date is also consistent with the remanent magnetization preserved in the lava flows.

The series of eruptions that produced the volcanic deposits at Cinder Cone were complex and are by no means completely understood. However, the new studies done by USGS scientists refute the purported accounts of an eruption in the early 1850's and confirm Diller's $(1891,1893)$ interpretation that Cinder Cone erupted in the latter half of the 17th century. They also suggest that the 1666 treering date proposed by Finch (1937) for his "second" explosive eruption at Cinder Cone might actually date the entire eruptive sequence.

This recent work of USGS scientists at Cinder Cone, in cooperation with the NPS, is helping to provide a better understanding of volcano hazards in the Lassen Volcanic National Park area. The work of these scientists is only part of the USGS Volcano Hazards Program's ongoing efforts to protect people's lives and property in all of the volcanic re-

Cinder Cone has a related, widespread ash deposit, seen here being examined by a U.S. Geological Survey scientist, which is identifiable for 8 to 10 miles from the cone. On the Old Bench and Painted Dunes lava flows, this ash is brightly oxidized because it fell on the lava flows when they were still hot. Because the oxidized ash has the same composition as the last lava flows erupted at Cinder Cone (the Fantastic Lava Beds flows), Cinder Cone must have formed in a single eruptive sequence that probably spanned no more than a few months.

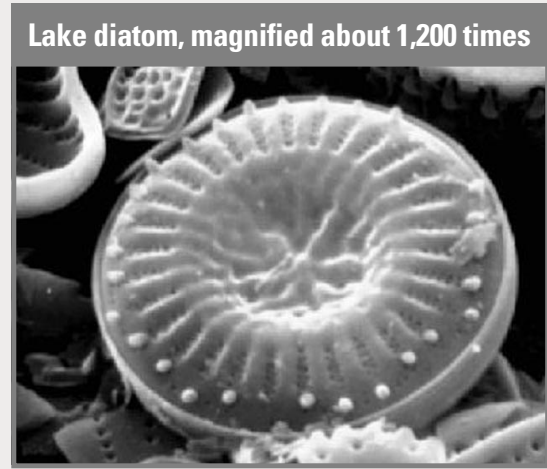

created by the accumulation on the lake bottom of diatoms, microscopic single-celled plants whose skeletons are made of opaline silica. When advancing lava flows entered the lake, they squeezed up some of the diatomite along their margins (see geologic map). Diatoms can provide information on the ages and environments of ancient freshwater and marine deposits.

gions of the United States, including the Pacific Northwest, eastern California, Wyoming, Alaska, and Hawaii.

Michael A. Clynne, Duane E. Champion, Deborah A. Trimble, James W. Hendley II, and Peter H. Stauffer

\section{Graphic design by}

Sara Boore and Susan Mayfield

Banner design by Bobbie Myers

COOPERATING ORGANIZATIONS

Lassen Park Foundation

National Park Service

U.S. Forest Service

\section{REFERENCES}

Diller, J.S., 1891, A late volcanic eruption in northern California and its peculiar lava: U.S. Geological Survey Bulletin 79, $33 \mathrm{p}$

Diller, J.S., 1893, Our youngest volcano: National Geographic Magazine, v. 4, p.93-96.

Finch, R.H., 1937, A tree ring calendar for dating volcanic events at Cinder Cone, Lassen Volcanic National Park, California: American Journal of Science, v. 33, p.140-146.

Finch, R.H., and Anderson, C.A., 1930, The quartz basalt eruptions of Cinder Cone, Lassen Volcanic National Park California: University of California Publications in the Geological Sciences, v. 19, p. 245-273.

Harkness, H.W., 1875, A recent volcano in Plumas County: California Academy of Sciences Proceedings, v. 5, p.408 412

Jones, A.E., 1928, Magnetism of Cinder Cone lava flows, Lassen Volcanic National Park, California: Hawaiian Volcano Observatory Bulletin, v. 16, p. 61-65.

For more information contact: Lassen Volcanic National Park

P.0. Box 100, Mineral, CA 96063 (530) 595-4444

http://www.nps.gov/lavo/

http://volcanoes.usgs.gov/

See also Volcano Hazards of the Lassen Volcanic National Park Area, California (USGS Fact Sheet 022-00) and Eruptions of Lassen Peak, California, 1914 to 1917(USGS Fact Sheet 173-98). 